\title{
TECHNIQUES AND TOOLS FOR ACHIEVING EFFECTIVE HUMAN RESOURCES MANAGEMENT: THEIR CONSTRAINTS IN AFRICA
}

\author{
E. O. TANDU, S. O. ABEKI AND B. G. NNAA
}

(Received 12, November 2008; Revision Accepted 3, February 2009)

\section{ABSTRACT}

African countries are classified under the less developed countries of the world with their attendant disabilities. Human resources management is not an exception. The successful management of Human Resources is one of the keys to the effective operations of an organization. Formal organizations are made up of people. They are set up in order to achieve certain objectives and goals. Therefore, the importance of human resources and its proper management cannot be over emphasized. This paper therefore examines The techniques and tools for achieving effective human resources management: Their constraints in Africa. It examines a number of definitional and theoretical postulations on human resources management that have inspired the specific techniques and tools discussed here. It attempts to discuss some specific techniques and tools like management by objectives (MBO), job analysis, job evaluation, performance appraisal, manpower planning, staff development, computers and informatics that are likely to impact positively on human resources management. And finally those constraints that diminish their effectiveness in Africa with some recommendations on the way forward

\section{INTRODUCTION}

Human resources management is a distinctive approach to employment management which seeks to achieve competitive advantage through the strategic deployment of highly committed and capable workforce, using an integrated array of cultural, structural and personnel techniques (Storey, 1995). Human resources management has become an important consideration for all organizations in an age of global competition in which all large-scale organizations must compete for resources whether they are in the public or private sector or are non-governmental organizations. increasing assertiveness and visibility of customers in the delivery of goods and services by these various organizations has also made it even more essential to secure and manage human resources as the most critical resource of any organization.

This paper is therefore very significant because Africar countries need to transform their public service systems from the passive and even negative roles of administration to actively developing and pursuing policies for synergizing the personnel function with overall proactive strategic management within the organization for better results. That is why African countries cannot ignore these tools and techniques for achieving effective human resources management considering the backwardness of their public service system which has negative effect on their development.

\section{DEFINITIONS OF HUMAN RESOURCES MANAGEMENT}

Human resources management is both a field of study and practice. It focuses on the whole process of planning, finding, building, coordinating, utilizing workforce and handling the formal systems for the management of people within the organization until and after their retirement (Peretomode and Peretomode,
2001). Hall and Goodale (1986) Consider human resources management as the process of bringing people and organization together so that the goals of each are met. Storey (1992) defines human resources management as "a distinctive approach to employment management which seeks to achieve competitive advantage through the strategic deployment of a highly committed and capable workforce, using an integrated array of cultural, structural and personnel techniques

From the three definitions above we conclude that human resources management is similar to the more conventional concept of personnel management, but it differs in three important respects as stated by (Olowu and Adamolekun 2002).

First, human resources management emphasizes the strategic role of personnel in managing organizational change. Organizational development is no longer a discrete activity, separate from personnel management but is now a component of human resources management. The second difference is that human resources management integrates human resources considerations to overall organizational strategy. Human resources management involves line managers and is no longer an exclusive responsibility of the personnel management department. This is because human resources management makes the important assumption that it is the quality and development of human resources that give any organization its competitive edge. Finally, instead of the preoccupation of personnel management with the administration of personnel rules for performing the threefold functions of personnel utilization, motivation, and protection. human resources management focuses on securing employees commitment to organizational goals.

Adamolekun (2002) stresses that, human resources management focuses on six major interrelated policy areas:

1) Management of change

E. O. Tandu, Department of Curriculum and Instructional Technology, Faculty of Education, Cross River State

University of Technology, Calabar- Nigeria.

S. O. Abeki, National Open University of Nigeria, Yenegoa Study Centre. Bayelsa State

B. G. Nnaa, Head of Department, Business Administration and Management. Rivers State Polytechnic. Bori 
3) Recruitment, selection, and socialization

4) Appraisal, training, and development

5) Reward system and

6) Communication.

It should be immediately evident that activities undertaken in one area have an impact on each of the others for example, the development of incentives or reward systems affects the ability of an organization to respond to rapid change. Similarly, communication ensures that all other policy areas are linked to one another through building and reinforcing the appropriate organizational culture around the organizational mission.

The practical significance of the new human resources management orientation for African Public administration system is that it underscores the need for the transformation of personnel departments in public sector organizations from a preoccupation with passive or even negative roles of administering to actively developing and pursuing policies for synergizing the personnel function with the overall proactive strategic management within the organization, focused on the six areas highlighted above. It also calls attention to the need to develop professional skills for managing the most critical of all organizational resources (personnel) rather than treat it as a residual responsibility that can be handled by anyone who cannot be otherwise productively engaged in the organization.

\section{THEORETICAL POSTULATIONS}

The existing literature on human resources management shows that most of the techniques and tools that are widely used are largely borrowed from the private sector. Both the public and private sectors accept the need to ensure the safety of their employees to provide satisfactory welfare services, and to establish working conditions that will attract good quality personnel committed to the achievement of organizational objectives. It is in respect of the personnel motivation function that several tools and techniques have been developed. These tools and techniques were refined during the 1950s and 1960s following the significant contribution of behavoural scientists to the improvement of management practice. The contributions of Federick Herzberg, Douglas McGregor, and Abraham Maslow were particularly outstanding.

Maslow is noted for what he calls the "hierarchy of needs" that each employee seeks to satisfy:

1) The physiological or basic needs (food, shelter, and clothing);

2) Security or safety needs;

3) Belonging or affection needs

4) Esteem or ego needs

5) Self actualization needs

Maslow's theory states that a personnel system that meets all these needs will produce satisfactory results. In his opinion, needs 3,4 and 5 are the most critical, since ordinarily most employers have covered needs 1 and 2.

Herzberg's contribution consist of identifying the elements in a job that produce satisfaction (the motivating factors or motivators) and those whose absence will produce dissatisfaction (the hygiene function). The motivators include achievement, recognition, responsibility, the work itself, and promotion aspects. The absence of one or more factor(s) will not lead a worker to leave a job, but their presence can motivate the worker. The hygiene factors include pay, fringe benefits, and the physical working conditions these factors help to maintain a worker hence they are also known as (maintenance factors) but they do not motivate workers.

McGregor simply postulates that there are two broad attitudes toward employees, and he calls these theories $X$ and $Y$.

\section{Theory $\mathrm{X}$}

It is pessimistic about man. It states that: Employees inherently dislike work and when ever possible, will attempt to avoid it. Since employees dislike work, they must be coerced, controlled, or threatened with punishment to achieve desired goals.

Employees will shirk responsibilities and seek formal direction whenever possible.

Most workers placed security above all other factors associated with work, and will display ambition.

Theory $Y$

It is optimistic about man. It states that Employees can view work as being as natural as rest or play.

Man will exercise self direction and seff control if he is committed to the objectives

The average person can leam to accepts, even seek, responsibility.

Man is creative that is the ability to make good decision, is widely dispersed throughout the population, and not necessarily the sole province of those in administrative functions.

There are important similarities in the theories of these three management thinkers. What is significant for our purpose is the way in which most of the specific tools and techniques of human resources management have been inspired, in varying degrees, by these theories.

SOME SPECIFIC TECHNIQUES AND TOOLS FOR ACHIEVING EFFECTIVE HUMAN RESOURCES MANAGEMENT

In Africa, as in most other developing countries the transfer of management practices from the developed countries has been seen as the only viable option, in the absence of proven local altematives Hence, even though there have been debates about the applicability of western management practices in nonwestern contexts, most public and private sector organizations in African countries have made efforts to implement these western management concepts. The techniques have been introduced mainly through multinational corporations, donor investment projects, technical assistance, fellowship, and training programmes. However the most important vehicle has been the periodic commissions reports that attempts to undertake wholesale reforms of the public sector. The most notable ones have been in Kenya, (1971) Ghana (1972), Nigeria (1974) Swaziland (1975) (Adamolekun 1983).

All these reports made a case for the implementation of a number of now management practices, some of which are to be discuss below. 
Management by Objectives

Management by objectives (MBO) can be defined, from the point of view of human resources management, as a system that seek to improve an organization's performance and to motivate, assess, and train employees by integrating their personal goals with the objectives of the organization. Management by objectives can be described as the major techniques that has been infaired by the theories of management thinkers reviewed above. The effective use of management by objectives requires that the objectives of an organization must be clarified. Managers and their subordinates are expected to set objectives jointly and to review performance (achievement and problems) at fixed intervals. The advantages of this technique in human resources management as stated by Olowu (1999), include the following: an increase in general efficiency, improved motivation through participation, and improved quality of work because of periodic performance review. Overall, the technique helps to ensure that motivation, training, and appraisal becomes shared responsibilities.

\section{Job analysis}

This is an exposition of the purpose, scope, duties and responsibilities of a particular job (Adamolekun 2001). For management to hire appropriate people, it must know in detail what task are to be performed and what the personnel and social characteristics of the work are. These determinations are accomplished through job analysis. Albert and Khedouri (1998) remind us that job analysis is the cornerstone of human resources management. Without thorough analysis of all jobs, it is difficuit to perform the other human resource functions adequately. A comprehensive assessment of all clerical, operational technical, and managerial jobs provides a strong foundation for making future selection, salary, training. performance appraisal, and promotional decisions.

\section{Job evaluation}

Job evaluation is a process of placing jobs in order of their relative worth. In order that employees may be paid fairly, the emphasis is on the demands and conditions of the job not on the qualification of the person performing the job. The prerequisite for effective job evaluation is specialization. Job evaluation facilitates pay administration by assisting in the determination of rates and helping to avoid arbitrariness (Paul 1983). Similarly, Cole (1990) defines job evaluation as "a technique for determining the size of one job compared with, another, and the relationship between the two, job evaluation schemes can broadly be divided into analytical and non analytical, the techniques forms the basis for wage and salary administration".

\section{Performance appraisal}

According to Cole (1990) this is review of an employee's performance in his or her job. It is a formal and systematic assessment and is usually made in a prescribed manner at a given time. Similarly, Albert (1998) sees performance appraisal as requiring managers to gather information on how effective each individual is at accomplishing delegated duties. Communicating this information to subordinates enables them to know how well they are doing and to correct less than acceptable behaviour. He further stated that, performance appraisal also permits management to identify the outstanding performers and in effect raise their performance standards by promoting them to more challenging positions.

\section{Management development}

Development refers to building skills that employees will need in order to perform effectively in a future position or job assignment (Khodouri 1998). In practice systematic development programmes are most often used to groom managers for promotion. As with training considerable analysis and planning are required for management development to be successful. The organization must first determine through performance appraisal what the abilities of its present managers are. Then, through job analysis, management determines what skills and abilities are needed to perform each line and staff job in the organization. This enables the organization to determine which of its managers are best qualified to fill each position and which require training and development. Managerial development is primarily undertaken, of course, to ensure that managers have the skills needed to attain organizational objectives.

\section{Manpower planning and staff development}

Manpower planning according to Storey (1992) has been defined 'as the attempt to forecast how many and what kind of employees will be required in the future and to what extent this demand is likely to be met'. The objectives are to ensure that an organization has adequate human resources to meet its short-term and long-term needs. Similarly, Ikeji in Duru, Ikejiani-Clark, and Mbat (eds) (2001) reminds us that, manpower planning requires "evolving personnel forecast and budget, administration of recruitment and selection policies and programmes, advertisement of jobs, testing, interviewing, development and transfer, interpretation of needs of the organization; records of labour turn over the analysis of absenteeism among others; manpower planning is useful in the areas of recruitment and training. Staff development as stated by Adamolekun, Laleye, and Kulemeka (1997) refers to "both the training and the education of an organization's staff as well as to the overall career development of each staff member". Training they stated is generally concerned with the acquisition of skills and education seeks to develop general ability". However, the general practice is that education and training programmes are established of all categories of staff, senior, intermediate, and junior.

\section{Computers and informatics}

Today computers are helping to revolutionize most of the human resources management activities in all organizations. Together with telecommunication and automated innovations, computers are having profound effects on employment patterns and work processes in the public services of most nations in the world. They have had great impact on the management of human resources, and information has helped to heighten the importance of human resources as strategic resource. They have also facilitated the introduction of ciranges aimed at cost reduction, better coordination, service responsiveness, and consumer satisfaction in many 
developed countries, especially in Africa (CAFRAD 1994).

From the foregoing, it could be discemed that the techniques and tools for achieving effective human resources management are indispensable for organizations that needs to achieve their objectives: We will now look at the constraints that have been the bane of Africa's applicetion of the techniques and tools for achieving effuctive human resources management.

\section{CONSTRANTS THAT HMDER EFFECTIVE HUNAN RESOURCES MANAGEMENT IN AFRICA}

These new management practices related to HRM have not atways functioned in the manner expected in the African public services. This is due to some constraints. A number of constraints hoving regard to Africa are discussed below;

\section{Cuttural relevence}

One of the most imiluential constraints is the culural retevance of these theorice to the African context. These manegement practices are transferred from the developed countries to Africa. These practices in the developed countries are based on the merit system and in Africa other criteria are used in the application of these practices. This entails the use of non-rational criteria, in most cases religion, tribe, social and other culturat considerations. The merit system is basically pushed aside. This has gone along way to affect the achievement of effective human resources management in Africa.

\section{The politics of managing change}

Another constraints for the poor application of management theories in Africa is the politics of managing change. All changes generates winners and losers, and the environment in these African countries is one that provide great opportunities for those who benefit from the status quo to offer successful resistance to change. Again, many reform initiatives fall to give attention to incentive for the successful introduction of innovations, and neither are innovations carried out in a consensual manner. African countries are skeptical about these management practice, they see them as imported and they treat them with skepticism.

\section{Organlation constraint}

The problems associated with the utillzation of the techniques and tools are not easy to solve, especially in pubtic sector orgenizations. Clarification of objectives is not easy, and the emphasis on quantifiable aspects of jobs could lead to the naglect of long-term objectives. At the interpersonel level, for instance, management by objectives will be difficult to vee in instances in which a maneger is not as competent as his or her subordinate which is a very common thing in Africa where those positions are not based on merit. Most organizations in Africa from evident gathered all badly structured and poorly directed. These tools and techniques most especially management by objectives cannot be introduced into a badly structured and poorty directed organization.

\section{Lack of investment In computer technology \\ Many African countries already have access to computer hardware and software but have yet to fully}

apply them to the management of their humen resources. For effective application of computers in - human resources management activities, there is the need for continuous professional training and considerable investment in computer technology in both hardware and software which many countries in the region can hardly afford. In addition, there is the prerequisite of reliable electricity as well as telecommunication infrastructure for the use of the internet. Although, the is improvement in telecommunicution. most African countries are lacking seriousty in the area of electricity (CAFRAD 1994).

\section{Lack of adequate trained personnel}

Training is expected to meet a range of objectives, notably skilled development, up grading and socialization of personnel into the service. But training has had a rather limited impact, quantitatively and qualitatively, in many African countries. Several reasons have been adduced for this situation. They include the following:

a. Training is often treated as a discrete event, not part of an overall programme of crganizational improvement.

b. Many trainers are selected on the basis of bureaucratic politics and patronage rather than on the basis of the greatest need.

c. Competent trainers are rare, as training is itself a poorty developed profession.

d. Training curricula and models are usually based on borrowed models that are rarely updated.

e. Classroom-base, academic-style teaching dominates most training programmes, raising serious questions of relevance.

f. Most training institutions are poorly financed and managed and are usually heavily dependent on government (Paul 1983).

\section{RECOMMENDATIONS}

Arising from the constraints reviewed in this paper, the researchers are of the opinion that, if the recommendations hightighted below are taken into consideration they will go along way to eliminate or reduce to the bearest minimum the constraints that has been the bane of effective human rescurces management in Africa.

In order to eliminate or reduce the cultural constraint the merit system is very important, but then it should be applied taking into consideration our pecullar nature as Africans. The merit criterion should bo the besis for selecting, appointing or employing people base. on tribe, religion, quota etc into the public service in Africa.

The politics of managing change has afrected the public service in Africa greatly. That is why it has become necessary to carry out the re-orientation of the people to make them see and accept change os a necessary factor that any society needs to move forward. The world is dynamic and Africa can not be len behind. Those who have the opportunity to carty out change in Africa should do it consensually.

Organizetions should be property structured and directed in Arica to clow for the effective applicetion of the merit system. A situation where organizations are 
badly structured and poorly directed, the lools and techniques most especially management by objective cannot be introduce in a badly and poorly directed organization.

For effective application of computers in human resources management activities there is the need for continuous professional training and investment in computer technology in both hardware and software. The should be reliable electricity and communication infrastructure for the use of internet.

Training should be seen as part of the overall programme of organizational improvement. it should be based on the greatest need and not bureaucratic politics. Competent trainers should be engaged and training itself should be properly developed as a profession. And finally, training curricula and models should be constantly updated to meet the need of the time.

\section{CONCLUSION}

The paper examined a number of definitional and theoretical postulations on human resources management that have inspired the specific techniques and tools for achieving effective human resources management. We went further to look at the techniques and tools like management by objectives (MBO), job analysis, job evaluation, performance appraisal, manpower planning and staff development, and computers and informatics that are likely to impact positively on human resources management. Some constraints that diminish the effectiveness of these techniques and tools in Africa were discussed. Finally, some recommendations were made on the way forward. From the foregoing, we come to the realization that, these techniques and tools are potent instruments for the achievement of effective human resources management in Africa to the extent, that, the constraints highlighted can be eliminated or reduced to the barest minimum bearing in mind to recommendations made above.

\section{REFERENCES}

Adamolekun, L., 1993. "A note on Civil Service Personnel Policy Reform in SubSaharan". International Journal of Public Sector Management 6(3): 38-46.
Adamolekun, L., 1983. Public Administration: A Nigerian and Comparative Perspective. London - Longman

Adamolekun, L., Laleye, M., and Kulemeka, N., 1994. "Malawi Institute of Management: A Partial Success Story", International Review of Administrative Science 63 (4): 529-542.

African Training and Research Centre in Administration for Development (CAFRAD), 1994 Proceeding of the Pam African Conference of Ministers of Civil Service on Inter-African Cooperation in Civil Service and Administrative Reform, Tanaler, Morocco, June.

Albert, $M$. and Khodour, F., 1998. Management $3^{\text {rd }}$ Edition. New York: Harper \& Row Publisher.

Cole, G. A., 1990. Management: Theory and Practice $3^{\text {ri }}$ Edition. London. DP Publication Limited.

Duru, E. J. C, Ikejiani-clark, M., and Mbat, D. O., 2001.Contemporary Issues in Pubic Administration. Calabar BAAJ International Company.

Hall. L. and Goodale D., 1986. Human Resources Strategy and the Personnel Functions. Contemporary Development in Human Resources Management: Paris: Eska.

Paul, S., 1983. Training for Public Administration in Developing Countries: A Review. World Bank Working Paper.

Peretomode, V. E. and Peretomode, O., 2001. Human Resources Management: Lagos. Obaroh and Ogbainaka Publishing Limited.

Olowu, B., 1999. "Redesigning African Civil Reform Joumal of Modern Africa Studies 37(1):

Storey, J., 1992. Development in the Management of Human Resources. Oxford: Block Wett. 